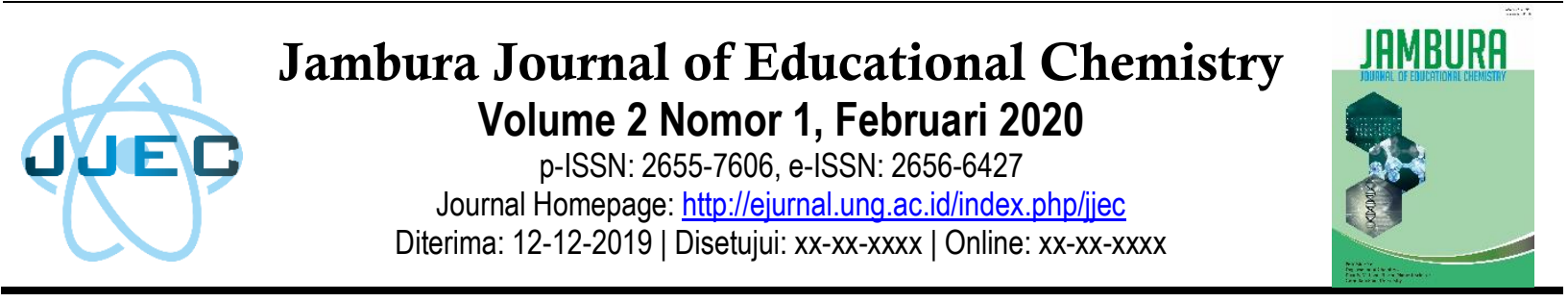

\title{
Implementasi Kecerdasan Emosional dan Minat Siswa pada Pembelajaran Kimia
}

\author{
Dewi Kurnia Sari'1, Siti Suryaningsih², dan Luki Yunita ${ }^{3}$ \\ 1,2,3Jurusan Pendidikan Kimia, Fakultas Ilmu Tarbiyah dan Keguruan, Universitas Islam \\ Negeri Syarif Hidayatullah Jakarta, Jl. Ir. H. Juanda No 95, Ciputat 15412, Indonesia \\ e-mail: 11dewikurniasar29@gmail.com
}

\begin{abstract}
Abstrak
Kimia merupakan pelajaran sulit karena memiliki konsep yang bersifat abstrak. Akibatnya siswa mengalami kesulitan belajar kimia sehingga hasil belajarnya rendah. Tujuan penelitian ini untuk mengetahui korelasi dan kontribusi dari kecerdasan emosional dan minat siswa terhadap hasil belajar siswa pada mata pelajaran kimia. Metode penelitian menggunakan deskriptif kuantitatif. Penelitian berlokasi di dua SMAN Kota Tangerang dengan populasi seluruh kelas X dan 300 siswa sebagai sampel menggunakan teknik purposive sampling. Instrumen penelitian berupa angket kecerdasan emosional dan minat serta nilai ujian akhir semester 1 untuk data hasil belajar siswa. Hasil penelitian menunjukkan bahwa 1) kecerdasan emosional dan minat memiliki korelasi dengan hasil belajar, 2) kecerdasan emosional dan minat memiliki kontribusi pada hasil belajar siswa sebesar 8,94\%. Kesimpulannya kecerdasan emosional dan minat berperan dalam meningkatkan pemusatan perhatian siswa pada saat mata pelajaran kimia berlangsung.
\end{abstract}

Kata Kunci: Hasil Belajar, Kecerdasan Emosional, Kesulitan Belajar, Mata Pelajaran Kimia, Minat

\section{PENDAHULUAN}

Peserta didik yang menempuh pendidikan diharapkan memiliki perubahan positif dalam dirinya, seperti tujuan pendidikan nasional yaitu melahirkan generasi muda yang memiliki pengetahuan luas dan berkepribadian baik. Perubahan positif perilaku siswa yang merupakan hasil dari proses belajar di sekolah dapat dilihat dari hasil belajarnya (Siagian, 2015). Menurut Slameto dalam (Saputra, 2017) Hasil belajar siswa dapat dipengaruhi oleh dua factor yaitu faktor eksternal dan faktor internal. Faktor eksternal hasil belajar berasal dari keluarga, sekolah, dan masyarakat. Sedangkan faktor internal berasal dari dalam diri siswa yang meliputi aspek jasmaniah dan aspek psikologis. Aspek jasmaniah yang mempengaruhi prestasi meliputi kesehatan dan cacat tubuh, sedangkan aspek psikologis meliputi perhatian, intelegensi, minat, bakat, kematangan emosi, motif, dan kesiapan. Siswa yang memiliki prestasi dalam mata pelajaran kimia adalah siswa

yang memperoleh nilai sesuai atau melampaui kriteria nilai yang ditetapkan oleh sekolah.

Faktor psikologis yang mempengaruhi hasil belajar yang dipandang paling essensial adalah kecerdasan, emosi, motivasi, bakat, dan lain-lain (Suralaga \& Solicha, 2010). Tujuan penelitian ini adalah menentukan korelasi dan kontribusi dari aspek psikologis hasil belajar yaitu kecerdasan yang berfokus pada kecerdasan emosional dan minat siswa terhadap kimia. Hasil belajar siswa yang rendah pada mata pelajaran kimia dikarenakan siswa mengalami kesulitan belajar. Akibatnya minat siswa menjadi rendah karena ketidakmampuan siswa dalam mengelola emosinya untuk mengatasi kesulitan belajar kimia. Kesulitan belajar yang dialami oleh siswa disebabkan karena kimia merupakan pelajaran yang sulit, seperti penelitian yang dilakukan oleh Ristiyani \& Bahriah 
(2016) menyebutkan bahwa kimia memiliki materi yang bersifat abstrak contohnya adalah penyetaraan reaksi dan energi, persamaan reaksi, reaksi oksidasi reduksi (Fatmawati, Rizmahardian, \& Kurniati, 2019) dan lain sebagainya. Hal ini menyebabkan siswa terutama siswa kelas $\mathrm{X}$ yang baru memasuki jenjang SMA mengalami kesulitan belajar sehingga hasil belajar pada mata pelajaran kimia rendah.

Hasil belajar dipengaruhi oleh kecerdasan emosional, berdasarkan penelitian yang dilakukan oleh (Pratama \& Corebima, 2016) kecerdasan emosional memiliki hubungan dan berkontribusi pada hasil belajar siswa. Sedangkan, penelitian yang dilakukan oleh (Rambe, Hasanah, \& Chairunnisa, 2017) menyebutkan bahwa sampai sekarang Intelligence Quotient (IQ) masih dijadikan simbol kecerdasan anak, sehingga banyak orang yang beranggapan bahwa IQ menjadi acuan berhasil atau tidaknya siswa di sekolah.

Hasil belajar siswa di Sekolah Menengah Atas (SMA) tidak bisa hanya mengandalkan intelegensi saja. Hal ini karena banyak ditemukan siswa yang memiliki intelegensi rendah berhasil meraih prestasi yang tinggi. Sebaliknya siswa yang mempunyai intelegensi tinggi tidak menjamin akan mendapatkan hasil belajar yang baik (Gusniwati, 2015). Sejalan dengan penyataan (Goleman, 2007), bahwa IQ hanya menyumbang $20 \%$ sebagai faktor yang mempengaruhi keberhasilan hidup seseorang, sedangkan $80 \%$ dipengaruhi faktor lain. Faktor lain yang dapat mempengaruhi keberhasilan hidup seseorang diantaranya adalah kecerdasan emosional dan minat.

Kecerdasan emosional merupakan kemampuan seseorang untuk mengelola emosi secara sehat (Khodijah, 2014). Menurut Uno (2010) kecerdasan emosional memiliki empat aspek yaitu kesadaran diri, pengaturan diri, empati, dan keterampilan sosial. Kecerdasan emosional penting bagi proses belajar siswa, hal ini sesuai dengan penelitian yang dilakukan oleh Sutisna et al., (2018) menjelaskan bahwa apabila emosional siswa tidak baik maka akan menurunkan keinginan belajar siswa. Hal ini dikarenakan kurangnya beberapa sifat siswa diantaranya rasa ingin tahu, kreatif, rasa untuk memperoleh simpati dari orang tua, guru, dan teman, serta enggan memperbaiki kegagalan. Oleh sebab itu, kecerdasan emosional memiliki peran yang penting bagi keberhasilan belajar siswa khususnya dalam mata pelajaran kimia.

Minat merupakan sebuah rasa ketertarikan terhadap suatu hal (Syah, 2014). Minat dapat dijadikan sebagai motivator intrinsik seseorang untuk melakukan suatu kegiatan (Djaali, 2018). Sebagai faktor psikologis yang mempengaruhi hasil belajar, minat memiliki hubungan dengan hasil belajar siswa pada mata pelajaran kimia (Rozikin, Amir, \& Rohiat, 2018). Artinya, semakin tinggi minat siswa untuk belajar kimia, maka akan semakin tinggi pula hasil belajar yang akan diperolehnya. Oleh karena itu, minat memiliki peran yang besar bagi proses pembelajaran kimia siswa.

Minat dapat diartikan juga sebagai kecenderungan seseorang untuk mengenang suatu kejadian (Djamarah, 2015). Kimia yang merupakan pelajaran sulit membuat banyak siswa yang tidak berminat untuk mempelajarinya lebih dalam (Akram et al., 2017). Oleh karena itu, tujuan dari penelitian ini adalah untuk menentukan sejauh mana kecerdasan emosional dan minat memiliki hubungan dengan pembelajaran kimia khususnya pada siswa kelas $\mathrm{X}$ yang baru memasuki jenjang SMA. Oleh karena itu, diharapkan penelitian ini dapat dijadikan sumber informasi tambahan bagi semua pihak bahwa pengembangan kecerdasan emosional dan minat sangat penting, bagi anak tidak hanya pintar dalam berpikir saja, tetapi juga memiliki kepribadian yang baik.

\section{METODE PENELITIAN}

Metode penelitian yang digunakan adalah kuantitatif deskriptif. Jenis penelitian yang digunakan adalah korelasional untuk menentukan sejauh mana hubungan kecerdasan emosional dan minat dengan hasil belajar siswa pada mata pelajaran kimia.

\section{Waktu dan Tempat Penelitian}

Penelitian dilakukan pada tanggal 6-11 Maret 2019 di dua SMAN Kota Tangerang.

\section{Target/Subjek Penelitian}

Populasi penelitian adalah seluruh siswa kelas $\mathrm{X}$ di dua SMAN Kota Tangerang yang 
berjumlah 13 kelas. Teknik pengumpulan sampel menggunakan purposive sampling yang merupakan teknik pengumpulan sampel dengan tujuan tertentu (Nursiyono, 2016). Sampel berjumlah 300 responden siswa/siswi kelas X program IPA yang dipilih masing-masing empat kelas dari setiap sekolah.

\section{Prosedur}

Penelitian ini merupakan penelitian korelasional yang dimulai dengan merumuskan masalah yaitu rendahnya hasil belajar siswa karena kecerdasan emosional siswa yang rendah dan minat siswa pada kimia yang kecil. Kemudian melakukan kajian pustaka tentang kecerdasan emosional, minat, dan hasil belajar siswa. Dilanjutkan dengan membuat instrumen untuk di uji validitas dan reliabilitasnya. Instrumen yang telah melalui tahap revisi disebarkan kepada responden untuk mengumpulkan data. Data kemudian diolah dan dibahas untuk memperoleh kesimpulan yaitu menentukan sejauh mana korelasi dan persentase kontribusi dari kecerdasan emosional dan minat terhadap hasil belajar siswa pada mata pelajaran kimia.

\section{Data, Intrumen, dan Teknik Pengumpulan Data}

Data penelitian dikumpulkan dengan menyebar angket kecerdasan emosional untuk menentukan kecerdasan emosional anak yang tercantum dalam buku berjudul Orientasi Baru Dalam Psikologi Pembelajaran karya Hamzah Uno (Uno, 2010) dan angket minat siswa yang diadopsi dari jurnal penelitian berjudul Exploring Student Declaining Interest In Chemistry karya Ayesha Ijaz, Tayyaba Akram, \& Hamid Ikram (Akram et al., 2017). Data hasil belajar siswa diperoleh dari nilai ujian akhir siswa pada mata pelajaran kimia di semester 1 .

\section{Teknik Analisis Data}

Teknik analisis data yang digunakan pada penelitian ini adalah kuantitatif deskriptif. Data yang diperoleh dari angket kecerdasan emosional, angket minat \& data nilai Penilaian Akhir Semester (PAS) siswa dideskripsikan dengan menampilkan mean, median, modus, dan standar deviasi.
Deskriptif statistik dari instrumen ini dilakukan dengan menggunakan software SPSS versi 22. Sebelum melakukan analisis inferensial, beberapa uji prasyarat yang dilakukan adalah uji normalitas, uji homogenitas, dan uji linieritas. Untuk menentukan persentase dari setiap aspek kecerdasan emosional dan aspek minat, digunakan acuan interpretasi dari persentase dalam Purwanto, (2012). Analisis inferensial yang dilakukan menggunakan uji korelasi ganda untuk menentukan hubungan antara kecerdasan emosional dan minat dengan hasil belajar siswa pada mata pelajaran kimia.

\section{HASIL DAN PEMBAHASAN}

Berdasarkan analisis data yang telah dilakukan, deskripsi data dari kecerdasan emosional, minat, dan hasil belajar siswa disajikan dalam Gambar 1 berikut:

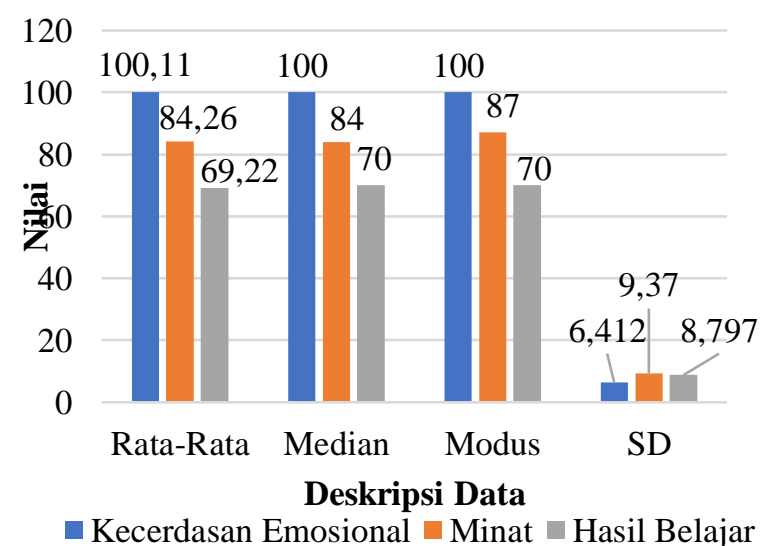

Gambar 1. Deskripsi Data Kecerdasan Emosional, Minat, dan Hasil Belajar

Berdasarkan Gambar 1, bahwa rata rata dari data kecerdasan emosional adalah 100,11; rata-rata minat adalah 84,26 , sedangkan rata-rata dari hasil belajar siswa adalah 69,22 . Median yang diperoleh dari data kecerdasan emosional adalah 100, minat memiliki nilai 84 , dan hasil belajar memiliki nilai 70. Modus kecerdasan emosional adalah 100, minat 87 dan hasil belajar adalah 70. Standar deviasi dari kecerdasan emosional adalah 6,41 ; minat adalah 9,37; dan hasil belajar adalah 8,97.

Persentase dari masing-masing aspek kecerdasan emosional dapat dilihat dalam bentuk grafik pada Gambar 2 


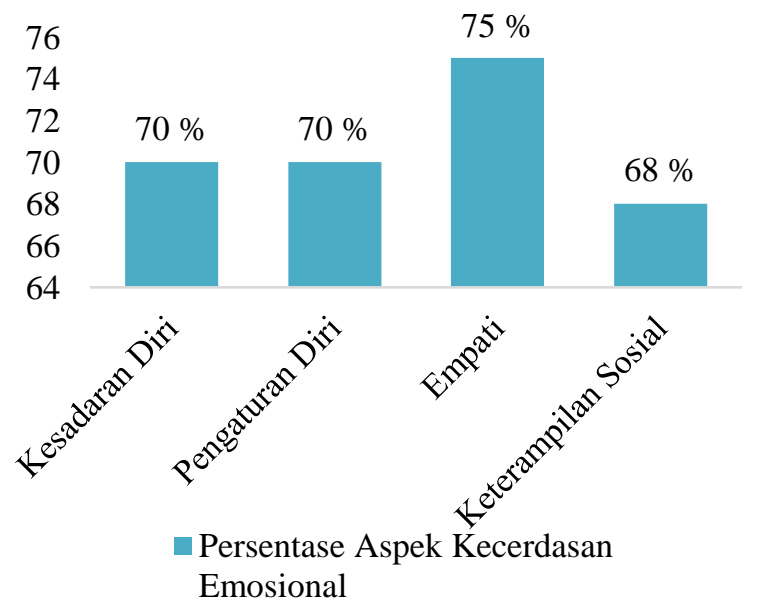

Gambar 2. Grafik Persentase Aspek Kecerdasan Emosional.

Berdasarkan Gambar 2, bahwa, kecerdasan emosional siswa tergolong baik karena memiliki persentase sebesar 94\%. Interpretasi dari tiap aspek tergolong kuat, dengan aspek empati yang memiliki persentase paling besar yakni 75\%. Aspek kesadaran diri dan pengaturan diri sebesar $70 \%$, dan aspek keterampilan sosial yang memiliki persentase sebesar $68 \%$.

Persentase dari aspek minat siswa pada mata pelajaran kimia dapat dilihat pada Gambar 3 sebagai berikut:

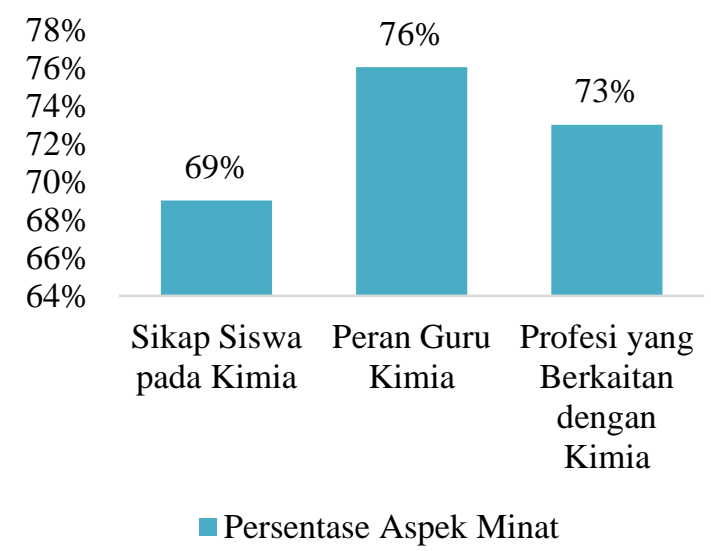

Gambar 3. Grafik Persentase Aspek Minat

Berdasarkan Gambar 3, bahwa minat siswa terhadap mata pelajaran kimia tergolong baik, karena secara keseluruhan memiliki persentase sebesar $73 \%$. Persentase dari tiap aspek minat siswa terhadap mata pelajaran kimia memiliki persentase yang tinggi. Aspek dengan persentase terbesar adalah peran guru kimia dengan persentase $76 \%$. Persentase sikap siswa terhadap kimia adalah 69\% sedangkan pengetahuan siswa tentang profesi yang berkaitan dengan kimia memiliki persentase sebesar $73 \%$.

Frekuensi nilai PAS yang diperoleh siswa, dapat dilihat pada Gambar 4 sebagai berikut:

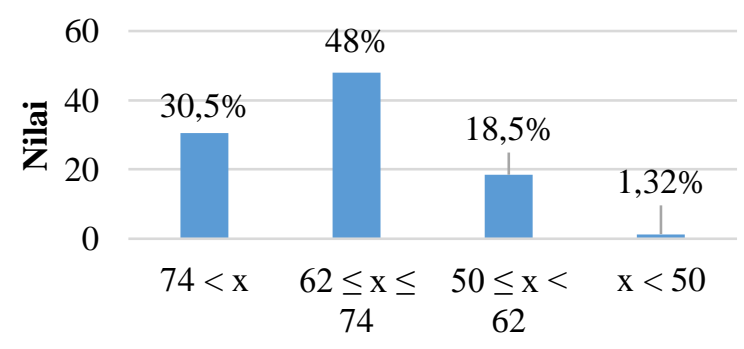

Rentang Nilai

Gambar 4. Grafik Persentase Hasil Belajar Siswa pada Mata Pelajaran Kimia.

Berdasarkan Gambar 4 standar Ketuntasan Kriteria Minimal (KKM) untuk mata pelajaran kimia di tempat penelitian adalah 75. Berdasarkan hasil analisis data, terdapat $30,5 \%$ siswa yang berhasil tuntas dari KKM. Siswa yang tidak tuntas memiliki nilai antara 62 sampai dengan 74 sebesar $48 \%$, nilai 50 sampai dengan 62 sebesar $18,5 \%$ dan siswa yang memiliki nilai di bawah 50 sebesar $1,32 \%$.

Hasil uji prasyarat yang dilakukan sebelum melakukan analisis inferensial yaitu uji korelasi dapat dilihat pada Tabel 1 sebagai berikut:

Tabel 1. Hasil Uji Prasyarat

\begin{tabular}{ccccc}
\hline Variabel & Alpha & Normalitas & Homogenitas & Linieritas \\
\hline $\begin{array}{c}\text { Kecerdasan } \\
\text { emosional }\end{array}$ & 0,065 & 0,727 & \\
Minat & 0,05 & 0,200 & 0,447 & 0,107 \\
$\begin{array}{c}\text { Hasil } \\
\text { belajar }\end{array}$ & 0,074 & 0,783 & \\
\hline
\end{tabular}

Berdasarkan Tabel 1, bahwa variabel kecerdasan emosional, minat, dan hasil belajar berdistribusi normal karena nilai signifikansi yang lebih besar dari 0,05. Ketiga variabel juga homogen karena memiliki signifikansi yang lebih besar dari 
0,05. Dan memiliki hubungan yang linier antara variabel kecerdasan emosional dan minat dengan hasil belajar karena nilai linieritas nya yang lebih besar dari 0,05 yaitu 0,107 .

Selanjutnya, untuk menentukan korelasi secara bersama-sama anatara variabel bebas yaitu kecerdasan emosional dan minat dengan variabel terikat yaitu hasil belajar siswa pada mata pelajaran kimia, dilakukan uji korelasi ganda dan diperoleh hasil pada Tabel 2 sebagai berikut:

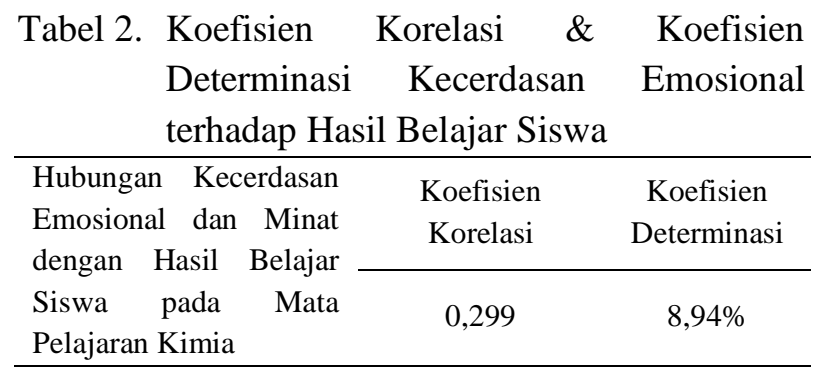

Berdasarkan Tabel 2, bahwa hubungan kecerdasan emosional dan minat mempunyai hubungan yang signifikan secara bersama-sama dengan hasil belajar peserta didik pada mata pelajaran kimia dengan nilai signifikansi sebesar 0,000 dan nilai $\mathrm{r}$ sebesar 0, 299 dengan koefisien determinasi sebesar $8,94 \%$. Hal ini menunjukkan bahwa kecerdasan emosional dan minat memiliki hubungan dengan hasil belajar siswa yang tergolong lemah yang ditandai dengan nilai koefisien korelasi yang memiliki interpretasi rendah. Hal ini sejalan dengan penelitian yang dilakukan oleh (Pratama \& Corebima, 2016) dan (Rahmawati, Djaja, \& Suyadi, 2018) bahwa kecerdasan emosional dan minat dengan hasil belajar mempunyai hubungan yang rendah, yang ditandai dengan koefisien determinasi sebesar $5,6 \%$ dan $11 \%$. Hubungan kecerdasan emosional dan minat dengan hasil belajar tersebut rendah, diprediksikan oleh banyak faktor lain yang dapat mempengaruhi hasil belajar siswa.

Kecerdasan emosional dan minat memiliki hubungan terhadap kesuksesan peserta didik dalam memahami konsep kimia di sekolah. Implementasi dari kecerdasan emosional dan minat bagi peserta didik dapat digunakan untuk menguasai konsep pada mata pelajaran kimia yang terkesan abstrak dan sulit. Kecerdasan emosional bertindak sebagai pengendali diri untuk mempertahankan fokus peserta didik dalam kegiatan belajar. Apabila peserta didik yang tidak memiliki kendali pada dirinya, maka akan terjadi gejolak batin yang akan mengurangi kemampuan peserta didik untuk bisa memusatkan perhatian. Dapat disimpulkan bahwa implementasi dari kecerdasan emosional penting untuk meningkatkan hasil belajar siswa pada mata pelajaran kimia.

Implementasi minat siswa sangat erat hubungannya dengan belajar, karena tanpa minat suasana belajar tidak akan menyenangkan. Minat memiliki peran yang sama dengan kecerdasan emosional yaitu membuat peserta didik memusatkan perhatian saat belajar kimia (Gusniwati, 2015). Pentingnya implementasi kecerdasan emosional dan minat dalam pembelajaran kimia sejalan dengan hasil penelitian yang dilakukan oleh (Suwardi \& Farnisa, 2018), bahwa minat dan kecerdasan emosional berpengaruh terhadap hasil belajar peserta didik. Dapat disimpulkan bahwa implementasi kecerdasan emosional dan minat menjadi faktor psikologis yang memiliki hubungan dengan hasil belajar siswa pada mata pelajaran kimia.

Kecerdasan emosional memiliki empat aspek yaitu kesadaran diri, pengaturan diri, empati, dan keterampilan sosial. Aspek dari kecerdasan emosional yang pertama adalah kesadaran diri, Persentase dari kesadaran diri siswa kelas $\mathrm{X}$ tergolong baik dengan persentase sebesar $70 \%$. Kesadaran diri siswa perlu dikembangkan, karena dapat membantu siswa untuk memiliki kemampuan sebagai pelajar yang mandiri di dalam berbagai bidang kehidupan. Guru memiliki peran yang penting dalam pengembangan kesadaran diri siswa. Hal ini dikarenakan guru memiliki waktu lebih banyak bertatap muka dengan siswa di dalam kelas. Guru perlu menjadikan pengembangan kesadaran yang baik pada siswa menjadi salah satu bagian dari tujuan utamanya dalam mengajar (Flavian, 2016).

Aspek yang kedua yaitu pengaturan diri siswa memiliki persentase yang sama yaitu $70 \%$. Pengaturan diri merupakan sebuah energi utama untuk mendorong, mengelola, dan mengarahkan keterampilan berpikir siswa (Munandar, 2017) Oleh karena itu, penting bagi siswa untuk memiliki kendali atau pengaturan diri yang baik agar mampu 
mengembangkan keterampilan berpikirnya. Hal ini berguna bagi siswa saat sedang menghadapi persoalan di bidang kimia yang terkesan sulit sehingga siswa mampu menghasilkan hasil belajar yang baik.

Aspek yang ketiga adalah empati siswa memiliki persentase sebesar $75 \%$. Empati pada siswa membantu siswa untuk meningkatkan hasil belajar siswa. Seperti penelitian yang dilakukan oleh (Ebinagbome \& Nizam, 2016) yang menyebutkan bahwa empati dapat meningkatkan motivasi berprestasi siswa sehingga membantu untuk meningkatkan keterampilan akademiknya. Aspek keterampilan sosial siswa memiliki persentase sebesar $68 \%$ dan tergolong baik. Keterampilan sosial berguna bagi siswa untuk menentukan bagaimana cara membina hubungan dengan orang lain dengan tepat. Sehingga membuat siswa memiliki banyak pilihan tentang bagaimana ia harus bersikap dan berpikir agar emosi dan intelektualitasnya bisa berjalan selaras (Munandar, 2017). Minat siswa pada kimia memiliki tiga aspek yaitu sikap siswa terhadap kimia, peran guru kimia. dan profesi yang berkaitan dengan kimia. Aspek dari minat yang pertama adalah sikap siswa terhadap kimia, aspek ini memiliki persentase sebesar 69\%. Minat dalam pembelajaran terdiri atas keinginan atau kesengajaan siswa untuk mengadakan perhatian dan keaktifan sehingga melahirkan rasa senang yang ditandai dalam bentuk perubahan perilaku dan sikap terhadap suatu ilmu pengetahuan dalam hal ini mata pelajaran kimia (Arlianty, 2017). Sikap siswa terhadap kimia memiliki peran yang penting dalam pencpaian prestasi siswa di bidang kimia (Delmang \& Gongdeng, 2016). Hal ini dikarenakan sikap siswa terhadap kimia menunjukkan dapat menunjukkan minat dan perasaannya dalam mempelajari kimia di kelas (Omwirhiren \& Anderson, 2016). Berdasarkan penelitian yang relevan, sikap merupakan aspek yang erat kaitannya dengan minat siswa dalam mempelajari kimia di sekolah. Karena semakin tinggi minat siswa, maka prestasinya di sekolah juga semakin baik.

Aspek yang kedua yakni peran guru kimia yang memiliki persentase paling besar yakni $75,7 \%$. Seorang guru kimia perlu memiliki kompetensi dalam ranah kognitif maupun non kognitif (Anthony, Shabaan, Nassor, \& Anthony, 2019) serta cara mengajar yang menyenangkan agar kimia mudah dipahami sehingga minat siswa terhadap kimia dapat berkembang. Peran guru di sekolah sudah baik karena mampu mengaitkan konsep kimia dengan fenomena dalam kehidupan seharihari. Pengetahun siswa terhadap profesi yang berkaitan dengan kimia di masa depan memiliki persentase sebesar $73,2 \%$. Penelitian menunjukkan bahwa siswa memiliki tingkat pengetahuan yang baik terhadap profesi masa depan yang berkaitan dengan kimia. penelitian sebelumnya menyebutkan bahwa profesi yang berkaitan dengan kimia sangat membosankan (Akram et al., 2017). Namun seiring berkembangnya zaman, banyak siswa yang mulai sadar bahwa profesi yang berkaitan dengan kimia menarik dan dapat mendatangkan pendapatan yang tinggi.

KKM mata pelajaran kimia yang ditetapkan di sekolah adalah 75. Berdasarkan data yang telah diperoleh, siswa yang berhasil meraih ketuntasan ada sebanyak 30,5\%. Artinya sebanyak 92 siswa yang mampu mengaplikasikan kecerdasan emosional dan minatnya untuk mempelajari kimia dan akhirnya berhasil lolos dari KKM yang telah ditetapkan. Kecerdasan emosional dan minat merupakan faktor psikologis yang dapat mempengaruhi penguasaan konsep suatu pelajaran. Apabila tingkat penguasaan konsep siswa pada kimia sudah baik, hasil belajarnya pun akan meningkat menjadi lebih baik. Sesuai dengan penelitian yang relevan menyebutkan bahwa kecerdasan emosional dan minat memiliki pengaruh terhadap hasil belajar siswa (Rahmawati et al., 2018). Artinya, kecerdasan emosional dan minat memiliki peran untuk dapat meningkatkan hasil belajar siswa pada mata pelajaran kimia. Kecerdasan emosional menjadikan diri siswa untuk bisa bisa menerima kemampuannya, mengatur dirinya, memiliki empati dan kemampuan membina hubungan dengan guru maupun temannya di sekolah dengan baik. Sedangkan dengan adanya minat, siswa akan merasa tertarik untuk belajar kimia.

Hasil dari analisis kecerdasan emosional dan minat siswa menunjukkan bahwa siswa kelas X 
di SMAN X Kota Tangerang memiliki tingkat kecerdasan emosional yang tinggi dan memiliki minat yang cukup baik terhadap mata pelajaran kimia. Sebagai faktor psikologis, implementasi kecerdasan emosional dan minat membantu siswa untuk memahami dan menguasai konsep suatu mata pelajaran. Hal ini berdasarkan penelitian yang relevan menyebutkan bahwa kecerdasan emsional dan minat memiliki pengaruh dengan penguasaan konsep suatu mata pelajaran (Gusniwati, 2015)

Apabila siswa memiliki penguasaan konsep yang baik pada mata pelajaran kimia, hasil belajarnya pun meningkat. Berdasarkan hasil penelitian, sebanyak $30,5 \%$ siswa yang tuntas sedangkan 69,5\% siswa belum tuntas. Di sisi lain, tingkat kecerdasan emosional dan minat siswa terhadap kimia tergolong sangat baik. Hal ini berarti sebanyak $30,5 \%$ siswa yang sudah mampu menggunakan faktor psikologisnya yaitu kecerdasan emosional dan minat pada kimia dengan baik sehingga berhasil menuntaskan standar nilai yang ditetapkan. Sedangkan siswa lainnya mungkin mampu menggunakan faktor psikologisnya tersebut di mata pelajaran lain selain kimia.

\section{KESIMPULAN}

Berdasarkan penelitian yang telah dilakukan, dapat diperoleh kesimpulan sebagai berikut: (1) kecerdasan emosional dan minat memiliki korelasi dengan hasil belajar siswa pada mata pelajaran kimia. dengan koefisien korelasi sebesar 0,299; (2) kecerdasan emosional dan minat merupakan faktor psikologis dari hasil belajar siswa yang menyumbang kontribusi sebesar 8,94\% terhadap hasil belajar siswa pada mata pelajaran kimia.

\section{UCAPAN TERIMA KASIH}

Peneliti mengucapkan terima kasih kepada keluarga \& semua pihak yang telah ikut mendukung sehingga penelitian ini dapat selesai. Khususnya kepada ibu Dr. Ir Hj. Suryaningsih, M.Si dan ibu Luki Yunita, M.Pd, semua pihak di Jurusan Pendidikan Kimia serta teman-teman yang tidak dapat disebutkan satu per satu.

\section{DAFTAR PUSTAKA}

Akram, T., Ijaz, A., \& Ikram, H. (2017). Exploring the Factors Responsible for Declaining Student's Interest in Chemistry. International Journal of Information and Education Technology, 7(2), 88-94. https://doi.org/10 18178/ijiet 201772847

Anthony, O. O., Shabaan, H. M., Nassor, S. M., \& Anthony, O. O. (2019). A Study of Performance in Chemistry among Lower Secondary Government Schools in Zanzibar, 7(2), 221-236.

Arlianty, W. N. (2017). An analysis of interest in students learning of physical chemistry experiment using Scientific approach. In International Journal of Science and Applied Science: Conference Series (Vol. 1, pp. 109_ 116).

https://doi.org/https://doi.org/10.20961/ijsas cs.v1i2.5 130

Delmang, T., \& Gongdeng, E. (2016). Ameliorating Sudent's Performance and Attitude towards Chemistry through Chemistry ProblemSolving Techniques (CPST). International Journal of Scientific Research in Education (IJSRE), 9(2), 41-47.

Djaali. (2018). Psikologi Pendidikan. Jakarta: Bumi Aksara. https://doi.org/10.4018/978-1-46664530-1.ch016

Djamarah, S. B. (2015). Psikologi Belajar. Jakarta: PT. Rineka Cipta.

Ebinagbome, M. E., \& Nizam, D. I. (2016). The Impact of Emotional Intelligence on Student's Academic Performance: International Journal of Accounting and Business Management, 4(1), 10-18. https://doi.org/10.24924/ijabm/2016.04/v4.is s1/10.18

Fatmawati, N., Rizmahardian, \& Kurniati, T. (2019). Analisis Kesulitan Belajar Berdasarkan Gaya Belajar Siswa Kelas X IPA pada Mata Pelajaran Kimia di MAS AlMustaqim Arang Limbung. Ar-Razi Jurnal Ilmiah, 7(1), 65-72.

Flavian, H. (2016). Towards teaching and beyond: Strengthening education by understanding students' self-awareness development. Power and Education, 8(1), 88-100. https://doi.org/https://doi.org/10.1177/17577 
43815624118

Goleman, D. (2007). Kecerdasan Emosional. (T. Hermaya, Ed.). Jakarta: PT. Gramedia Pustaka Utama.

Gusniwati, M. (2015). Pengaruh kecerdasan emosional dan minat belajar terhadap penguasaan konsep matematika siswa SMAN di kecamatan Kebon Jeruk. Formatif: Jurnal Ilmiah Pendidikan MIPA, 5(1).

Khodijah, N. (2014). Psikologi Pendidikan. Jakarta: PT. Raja Grafindo Persada.

Munandar, H. (2017). Hubungan Kecerdasan Emosional dengan Hasil Belajar Siswa Kelas XI IPA SMA Negeri di Kota Parepare pada Mata Pelajaran Kimia The Correlation between Emotional Intelligence with Learning Result of Grade XI IPA Students at SMAN in Parepare on Chemical Subjec, 18(1), 39-47.

Nursiyono, J. A. (2016). Kompas Teknik Pengambilan Sampel. Bogor: IN MEDIA.

Omwirhiren, E. M., \& Anderson, F. E. (2016). Effect of Class Size and Students' Attitude on Academic Performance in Chemistry at Demonstration Secondary School, Ahmadu Bello University Zaria, Nigeria. IOSR Journal of Research \& Method in Education, 6(1), 1-6. https://doi.org/10.9790/738806120106

Pratama, A. T., \& Corebima, A. D. (2016). Contribution Emotional Intelligence on Cognitive Learning Result of Biology of Senior High School Students in Medan, Indonesia. International Journal of Environmental7 Science Education, 11(15), 8077-8087.

Purwanto, N. (2012). Prinsip-Prinsip dan Teknik Evaluasi Pengajaran. Bandung: PT. Remaja Rosdakarya.

Rahmawati, K. P., Djaja, S., \& Suyadi, B. (2018). Pengaruh Minat Belajar Dan Kecerdasan Emosional Terhadap Prestasi Belajar Siswa Kelas Xi Ips Sma Negeri 1 Prajekan Kabupaten Bondowoso Tahun Ajaran 2016/2017. JURNAL PENDIDIKAN EKONOMI: Jurnal Ilmiah Ilmu Pendidikan,
Ilmu Ekonomi Dan Ilmu Sosial, 11(2), 61-68. https://doi.org/https://doi.org/10.19184/jpe.v $11 \mathrm{i} 2.6448$

Rambe, N. A. P., Hasanah, U., \& Chairunnisa, N. (2017). Hubungan Kecerdasan Emosional Dengan Hasil Belajar Anak Usia Dini, 6(2), 90-94.

Ristiyani, E., \& Bahriah, E. S. (2016). Analisis kesulitan belajar kimia siswa di SMAN X Kota Tangerang Selatan. Jurnal Penelitian Dan Pembelajaran IPA, 2(1), 18-29. https://doi.org/https://doi.org/10.30870/jppi. v2i1.431

Rozikin, S., Amir, H., \& Rohiat, S. (2018). Hubungan Minat Belajar Siswa dengan Prestasi Belajar Siswa Pada Mata Pelajaran Kimia di SMA Negeri 1 Tebat Karai dan SMA Negeri 1 Kabupaten Kepahiang, 2(1), 78-81.

Saputra, S. (2017). Hubungan Regulasi Emosi dengan Hasil Belajar Siswa. Konselor, 6(3), 96-100.

https://doi.org/https://doi.org/10.24036/0201 7637698-0-00

Siagian, R. E. F. (2015). Pengaruh minat dan kebiasaan belajar siswa terhadap prestasi belajar matematika. Formatif: Jurnal Ilmiah Pendidikan MIPA, 2(2). https://doi.org/https://doi.org/10.30998/form atif.v2i2.93

Suralaga, F., \& Solicha. (2010). Psikologi Pendidikan. Jakarta: Lembaga Penelitian UIN Syarif Hidayatullah Jakarta.

Sutisna, T., Yusmansyah, \& Andriyanto, R. E. (2018). Meningkatkan Kecerdasan Emosi Dengan Menggunakan Konseling Client Centered, (1), 1-14.

Suwardi, I., \& Farnisa, R. (2018). Hubungan Peran Guru Dalam Proses Pembelajaran Terhadap Prestasi Belajar Siswa. Jurnal Gentala Pendidikan Dasar, 3(2), 181-202.

Syah, M. (2014). Psikologi Pendidikan dengan Pendekatan Baru. Bandung: PT. Remaja Rosdakarya.

Uno, H. (2010). Orientasi Baru dalam Psikologi Pembelajaran. Jakarta: PT. Bumi Aksara. 